\title{
Article \\ Chondracanthus teedei var. lusitanicus: The Nutraceutical Potential of an Unexploited Marine Resource
}

\author{
Diana Pacheco ${ }^{1}\left(\mathbb{D}\right.$, João Cotas $^{1}{ }^{1}$, Andreia Domingues ${ }^{2}$, Sandrine Ressurreição ${ }^{2,3}$ (D), Kiril Bahcevandziev ${ }^{2,3}$ \\ and Leonel Pereira $1, *$ (D) \\ 1 MARE-Marine and Environmental Sciences Centre, Department of Life Sciences, University of Coimbra, \\ Calçada Martim de Freitas, 3000-456 Coimbra, Portugal; diana.pacheco@uc.pt (D.P.); jcotas@uc.pt (J.C.) \\ 2 Polytechnic of Coimbra, Coimbra Agriculture School, Bencanta, 3045-601 Coimbra, Portugal; \\ 21829002@esac.pt (A.D.); sandrine@esac.pt (S.R.); kiril@esac.pt (K.B.) \\ 3 Research Center for Natural Resources, Environment and Society (CERNAS), \\ Applied Research Institute (I2A), Coimbra Agriculture School, Bencanta, 3045-601 Coimbra, Portugal \\ * Correspondence: leonel.pereira@uc.pt; Tel.: +351-239-240-782
}

Citation: Pacheco, D.; Cotas, J.; Domingues, A.; Ressurreição, S.; Bahcevandziev, K.; Pereira, L. Chondracanthus teedei var. lusitanicus: The Nutraceutical Potential of an Unexploited Marine Resource. Mar. Drugs 2021, 19, 570. https:/ / doi.org/10.3390/md19100570

Academic Editor: Marialuisa Menna

Received: 14 September 2021

Accepted: 11 October 2021

Published: 14 October 2021

Publisher's Note: MDPI stays neutral with regard to jurisdictional claims in published maps and institutional affiliations.

Copyright: (c) 2021 by the authors. Licensee MDPI, Basel, Switzerland. This article is an open access article distributed under the terms and conditions of the Creative Commons Attribution (CC BY) license (https:// creativecommons.org/licenses/by/ $4.0 /)$.

\begin{abstract}
Presently, there is a high demand for nutritionally enhanced foods, so it is a current challenge to look at new raw food sources that can supplement beneficially the human diet. The nutritional profile and key secondary metabolites of red seaweeds (Rhodophyta) are gaining interest because of this challenge. In this context, the possible use of the red seaweed Chondracanthus teedei var. lusitanicus (Gigartinales) as a novel nutraceutical source was investigated. As a result, we highlight

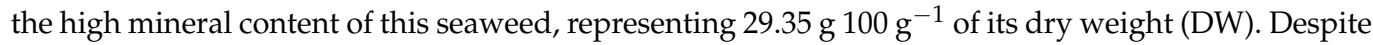

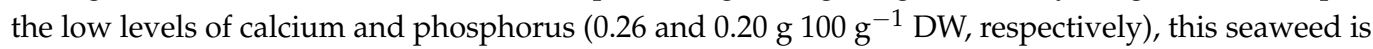
an interesting source of nitrogen and potassium (2.13 and $2.29 \mathrm{~g}^{-1} \mathrm{DW}$, accordingly). Furthermore,

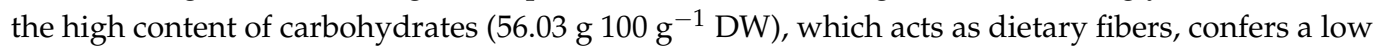
caloric content of this raw food source. Thus, this study demonstrates that $C$. teedei var. lusitanicus is in fact an unexploited potential resource with the capability to provide key minerals to the human diet with promising nutraceutical properties.
\end{abstract}

Keywords: red seaweed; nutritional characterization; nutraceutical; bioactive compounds

\section{Introduction}

The world's population is rapidly increasing, placing pressure on traditional food sources, and causing adverse impacts all over the world. As a result, there is a need to discover new raw food sources that can provide vital nutrients and minerals to humans to aid body cell function [1]. Due to the overexploitation of arable land, seaweed has potential for food supply, as it does not compete with terrestrial plants, and can be produced in different systems such as in depleted salt pans, estuarine water, or offshore farming systems [2].

There are several records that show that seaweed has been incorporated in the daily diet of coastal populations and cultures in Europe, Japan, and China since ancient times [3-6]. Currently, Europe consumes nearly 97 tons of seaweeds each year, of which the majority are imported [7].

Allied to the need to provide novel nutritious and healthy food sources to ensure global food security, seaweeds are being explored to be included in a list of possible food sources for animal and human diets [8,9].

Red seaweeds are recognized as a possible source of several unique metabolites with a variety of health benefits, in addition to their considerable contribution to the nutritional and industrial supplies [10]. For example, algal polysaccharides contribute as low caloric food sources, acting as anti-obesity agents, since these compounds are not digested by the human organism and provides the sense of satiety [11]. Furthermore, seaweeds synthesize essential fatty acids and essential amino acids, which are only acquired through the daily 
diet [12]. Because macroalgae are so rich in a variety of minerals that are needed for human health, red seaweeds are seen as valuable resources to be used as nutraceuticals $[13,14]$. Structural functions, such as tissue and bone synthesis, as well as regulatory functions, such as enzymatic activity, oxygen transport, and neurotransmission are supported by minerals acquired through the daily diet [12-15]. In fact, chronic diseases, such as obesity, diabetes, cardiovascular diseases, and the increased risk of certain types of cancers are related to consumption patterns and dietary factors [16]. Mineral elements are connected with organic substances, so the lack in one mineral will have an impact on the functioning of others [17]. For this reason, adequate mineral intake is needed to maintain the proper functioning of the human organism and cell homeostasis [12,16]. Minerals, such as calcium, magnesium, phosphorus, sodium, and potassium are required in larger quantities than trace minerals, such as iron, zinc, or copper [17]. Nevertheless, the ingestion of these trace elements is equally important to other minerals [18]. A favorable balance of mineral elements is required for the body to generate new tissue during growth, pregnancy, lactation, and other specific stress situations [17]. Moreover, the requirements of minerals intake vary according to the age and gender [17-19]. For instance, women during pregnancy are more likely to have low iron and calcium levels because their food consumption does not always match their needs, putting them at risk of developing anemia or osteoporosis, respectively [16]. Furthermore, due to poor-quality diets, diseases and therapies with an impact on a nutrient absorption or use, many people, particularly the senior population, are exposed to mineral deficiencies [18].

However, more crucial than emphasizing the health benefits of consuming seaweeds, is ensuring its long-term production through aquaculture while preserving its nutritional features [1,2]. Novel food sources, such as seaweeds, do not compete with ecological niches (sustainable food source), must present an important nutritional content in order to be used as nutraceutical output in the human diet [1], to reduce disease incidence, such as cancer, cardiovascular-associated diseases and problems related with undernourishment [1]. However, in the seas there are also wild and unstudied seaweeds that could be harmful for human health, when consumed, due to their retention of heavy metals, toxins and noxious chemicals, leading to the need for monitoring their production and/or harvesting [2,14].

One of the lesser known seaweeds, Chondracanthus teedei, has already proved to be a viable food source, and a well-adapted species that can be produced through aquaculture $[20,21]$, showing that may be grown with consistency in terms of nutrients, assuring as a safe food product and, decreasing the risk of dangerous compounds ingestion [1,2].

The red seaweed Chondracanthus teedei var. lusitanicus (Gigartinales), which inhabits the Portuguese sea, is a variation of the species Chondracanthus teedei that can be found in the Atlantic Ocean, Mediterranean and Black Sea [22]. C. teedei var. lusitanicus (J.E. De Mesquita Rodrigues) Bárbara and Cremades 1996 (Figure 1) is a cosmopolitan species typically present on lower intertidal and shallow subtidal habitats, can be found in semiexposed or protected areas, tolerates mud and/or sand [23]. Its biochemical, but not nutritional, composition varies depending on life cycle stage, geographical location, and the harvesting season [24].

It is highlighted in the literature that the nutritional potential of $C$. teedei in the human diet [1] but less known in C. teedei var. lusitanicus. C. teedei var. lusitanicus has already shown some fascinating properties, synthesizing sulfated polysaccharides (carrageenans) with antifungal activity [24], considered to be, potentially, an edible seaweed well-suited for consumption either fresh or processed [25] and sustainably produced by aquaculture [26]. For this reason, the aim of this study was to assess the nutritional profile of $C$. teedei var. lusitanicus, collected from its natural habitat, and to evaluate whether it has the potential to be a nutraceutical food source for humans. 


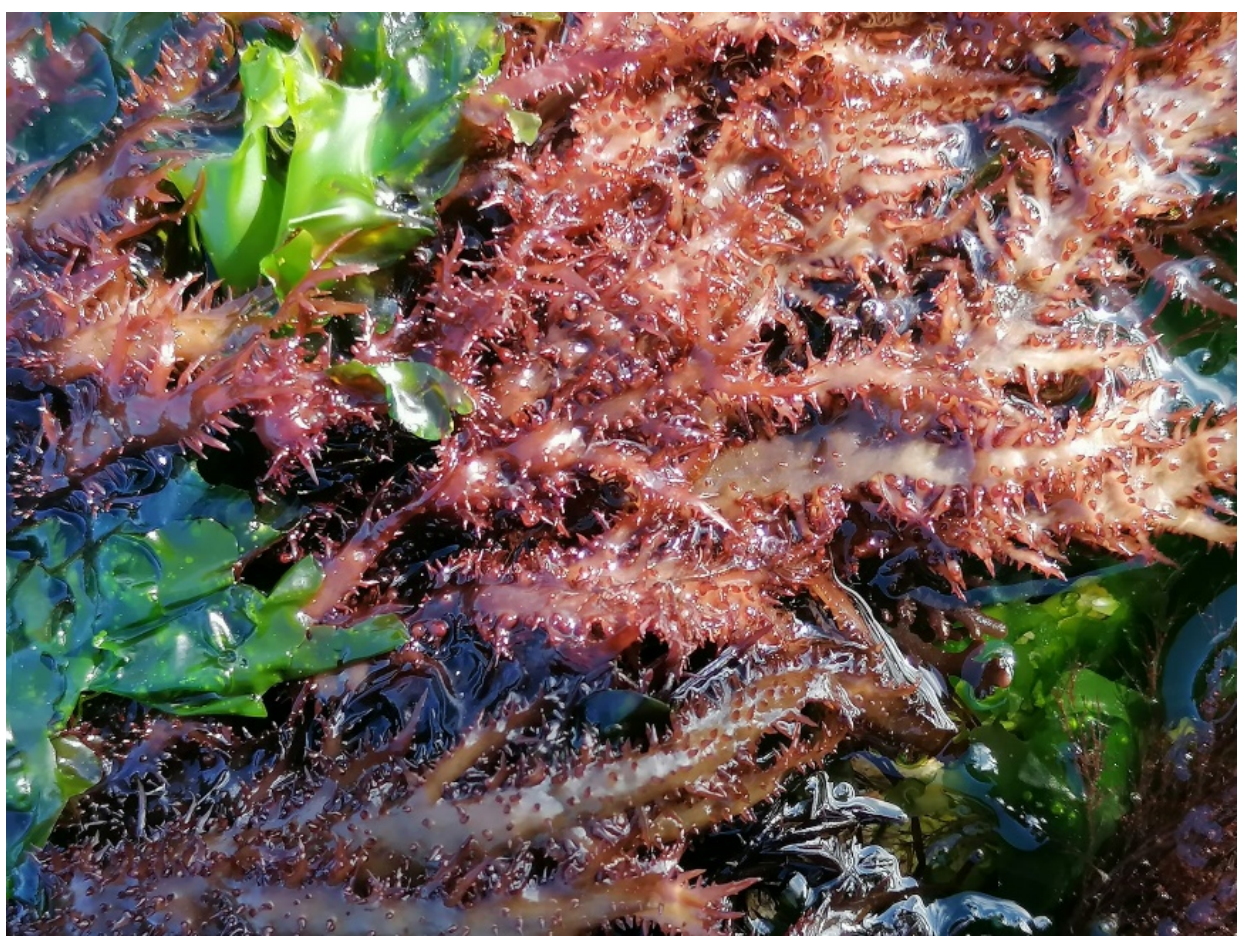

Figure 1. Chondrachantus teedei var. lusitanicus (fructified female gametophyte) in Buarcos Bay (Figueira da Foz, Portugal).

\section{Results}

\subsection{Macro- and Micro-Element Profile}

The red seaweed C. teedei var. lusitanicus has shown an interesting macro- and microelement profile (Table 1), exhibiting a high content in nitrogen and potassium (2.13 and

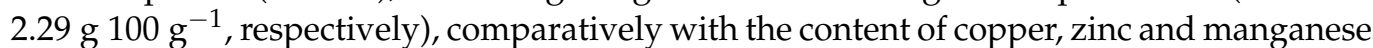

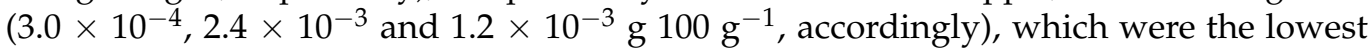
values in the elemental analysis of this seaweed biomass.

Table 1. Macro- and micro-elements characterization of the dried biomass of $C$. teedei var. lusitanicus. Results are expressed in mean \pm standard deviation. Nutritional value in $7 \mathrm{~g}$ of $C$. teedei var. lusitanicus according to the established Dietary Reference Intake (DRI) [1,27]. NA—Non applicable.

\begin{tabular}{lccc}
\hline Macro- and Micro-Elements & $\mathbf{g ~} \mathbf{1 0 0} \mathbf{~ g}^{-\mathbf{1}}$ & $\begin{array}{c}\mathbf{7} \text { g of } \text {. teedei var. } \\
\text { lusitanicus } \mathbf{( g )}\end{array}$ & DRI (\%) \\
\hline Nitrogen & $2.13 \pm 0.01$ & $\mathrm{NA}$ & $\mathrm{NA}$ \\
Phosphorus & $0.20 \pm 0.01$ & $1.4 \times 10^{-2}$ & 2 \\
Calcium & $0.26 \pm 0.03$ & $1.82 \times 10^{-2}$ & 2.27 \\
Magnesium & $0.86 \pm 0.02$ & $6.02 \times 10^{-2}$ & 16.05 \\
Potassium & $2.29 \pm 0.07$ & $1.60 \times 10^{-1}$ & 8.02 \\
Iron & $0.02 \pm 0.03$ & $1.28 \times 10^{-3}$ & 9.15 \\
Copper & $3.0 \times 10^{-4} \pm 3.0 \times 10^{-5}$ & $2.33 \times 10^{-5}$ & 2.33 \\
Zinc & $2.4 \times 10^{-3} \pm 1.0 \times 10^{-4}$ & $1.68 \times 10^{-4}$ & 1.68 \\
Manganese & $1.2 \times 10^{-3} \pm 1.0 \times 10^{-5}$ & $8.40 \times 10^{-5}$ & 4.20 \\
\hline
\end{tabular}

\subsection{Nutritional Evaluation}

When the nutritional evaluation (Table 2) of the fresh (FW) and dried (DW) C. teedei var. lusitanicus biomass weight was analyzed, it was observed that the DW is more encouraging from a nutritional aspect. A major part of this seaweed is composed of water. Meanwhile, it is highlighted that among the nutritional components analyzed that both FW and DW, contain a high content of crude carbohydrate presenting respectively 7.55 and 


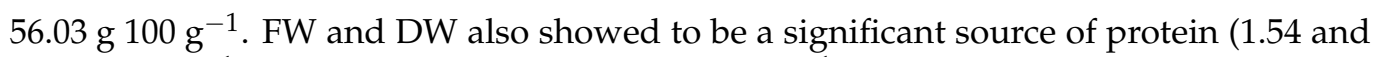

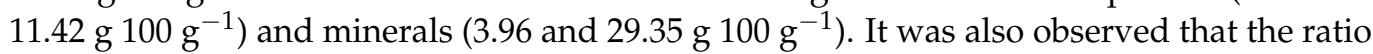
DW:FW of C. teedei var. lusitanicus is 1:7, for all nutritional parameters, meaning that $1 \mathrm{~g}$ of dried algal biomass corresponds, nutritionally, to $7.4 \mathrm{~g}$ of fresh seaweed.

Table 2. Nutritional characterization of the fresh (FW) and dried (DW) C. teedei var. lusitanicus biomass weight. Results are expressed in mean \pm standard deviation. Nutritional value in $7 \mathrm{~g}$ of $C$. teedei var. lusitanicus according to the established Dietary Reference Intake (DRI) [1,27]. NA-Non applicable.

\begin{tabular}{|c|c|c|c|c|c|}
\hline & \multicolumn{2}{|c|}{$\begin{array}{l}\text { C. teedei var. lusitanicus } \\
\qquad\left({\left.\mathrm{g} 100 \mathrm{~g}^{-1}\right)}^{-1}\right.\end{array}$} & \multirow{2}{*}{\multicolumn{2}{|c|}{$\begin{array}{c}7 \mathrm{~g} \text { of } C . \text { teedei } \\
\text { var. Iusitanicus } \\
\text { (g) }\end{array}$}} & \multirow[t]{2}{*}{$\begin{array}{l}\text { DRI } \\
(\%)\end{array}$} \\
\hline & FW & DW & & & \\
\hline Moisture & $86.52 \pm 0.18$ & NA & NA & NA & NA \\
\hline Ash & $3.96 \pm 0.07$ & $29.35 \pm 0.13$ & $1: 7.4$ & 2.1 & NA \\
\hline Total lipid & $0.19 \pm 0.01$ & $1.42 \pm 0.01$ & $1: 7.4$ & 0.10 & 0.14 \\
\hline Fiber & $0.24 \pm 0.01$ & $1.78 \pm 0.09$ & $1: 7.4$ & 0.13 & 0.49 \\
\hline Protein & $1.54 \pm 0.01$ & $11.42 \pm 0.01$ & $1: 7.4$ & 0.80 & 1.59 \\
\hline Total carbohydrate & $7.55 \pm 0.12$ & $56.03 \pm 0.05$ & $1: 7.4$ & 3.98 & 1.50 \\
\hline Energy (Kcal $100 \mathrm{~g}^{-1}$ ) & $38 \pm 0.47$ & $283 \pm 0.23$ & $1: 7.4$ & $19.81 *$ & 0.99 \\
\hline
\end{tabular}

${ }^{*}$ Measured in total Kcal.

\subsection{Polyssacharides from C. teedei var. lusitanicus}

Carbohydrates are the most abundant nutrient in C. teedei var. lusitanicus (Table 3), emphasizing the polysaccharide content of this seaweed. When compared all samples, the female and male gametophytes of $C$. teedei var. lusitanicus produced the highest polysaccharide quantity, 40.9 and $42.1 \%$, respectively.

Table 3. Polysaccharide quantification and nutritional value in $7 \mathrm{~g}$ of C. teedei var. lusitanicus according to the established Dietary Reference Intake (DRI) [1,27].

\begin{tabular}{llll}
\hline $\begin{array}{l}\text { Chondracanthus teedei var. } \\
\text { lusitanicus } \text { Life Cycle Phase }\end{array}$ & DW (\%) & $\begin{array}{l}\text { 7 g of } \text { C. teedei var. } \\
\text { lusitanicus } \mathbf{~ ( g ) ~}\end{array}$ & DRI (\%) \\
\hline Female gametophyte & $40.9 \pm 1.5$ & 2.86 & 11.45 \\
Male gametophyte & $42.1 \pm 4.5$ & 2.95 & 11.79 \\
Tetrasporophyte & $28.1 \pm 8.1$ & 1.97 & 7.87 \\
\hline
\end{tabular}

\subsubsection{FTIR-ATR}

The isolated polysaccharides were examined using FTIR-ATR. This spectroscopic approach enabled quick, nondestructive polysaccharide characterization with a small amount of sample [28]. The bibliography was used to assist the collection of the spectra [29,30].

Along with the presence of three shoulder peaks at $905 \mathrm{~cm}^{-1}, 930 \mathrm{~cm}^{-1}$, and $1070 \mathrm{~cm}^{-1}$ in the FTIR spectrum, which is associated with the presence of theta-carrageenan, the C. teedei var. lusitanicus tetrasporophyte (Figure 2 and Table 4) has a hybrid xi/theta carrageenan [25,29]. Moreover, the tetrasporophyte phase of $C$. teedei var. lusitanicus, has a large peak in $830 \mathrm{~cm}^{-1}$, which is typical of two principal peaks near the xi-carrageenan. The large and prominent peak in this case reveals that this life cycle phase of $C$. teedei var. lusitanicus tetrasporophyte (Figure 3A) possesses also an xi/theta carrageenan [25]. The FTIR-ATR spectra of male and female C. teedei var. lusitanicus gametophytes (Figure 2B,C) were identical, indicating the existence of a hybrid kappa/iota carrageenan (present in the peaks: kappa: 930 and $845 \mathrm{~cm}^{-1}$; iota: $805 \mathrm{~cm}^{-1}$ ). 


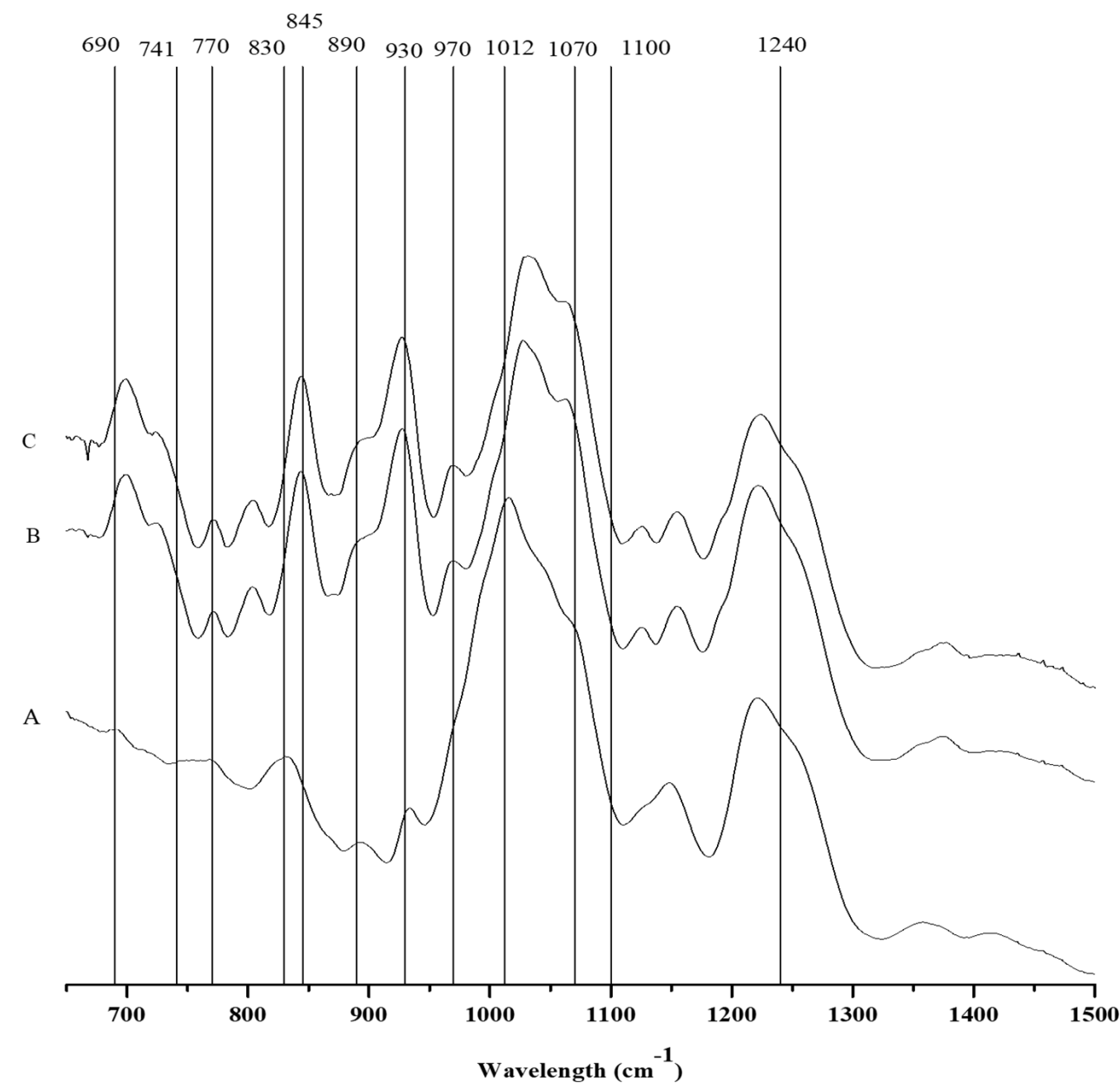

Figure 2. FTIR-ATR spectra of the carrageenophytes: A: Chondracanthus teedei var. lusitanicus tetrasporophyte, B: C. teedei var. lusitanicus male and C: C. teedei var. lusitanicus female gametophytes.

Table 4. FTIR-ATR bands identification and characterization of the C. teedei var lusitanicus (CTGF-female gametophyte, CTGM- male gametophyte, CTT- tetrasporophyte), based on the literature [30,31].

\begin{tabular}{|c|c|c|c|c|c|}
\hline $\begin{array}{l}\text { Wave Number } \\
\quad\left(\mathrm{cm}^{-1}\right)\end{array}$ & Bound & Compound & CTGF & CTGM & CTT \\
\hline 805 & $\begin{array}{c}\mathrm{C}-\mathrm{O}-\mathrm{SO}_{3} \text { on } \mathrm{C}_{2} \text { of } \\
\text { 3,6-anhydrogalactose }\end{array}$ & DA2S & + & + & - \\
\hline $825-830$ & $\mathrm{C}-\mathrm{O}-\mathrm{SO}_{3}$ on $\mathrm{C}_{2}$ of galactose & G/D2S & - & - & + \\
\hline 845 & D-galactose-4-sulfate & G4S & + & + & - \\
\hline 867 & $\mathrm{C}-\mathrm{O}-\mathrm{SO}_{3}$ on $\mathrm{C}_{6}$ of galactose & G/D6S & + & + & - \\
\hline $890-900$ & Unsulfated b-D-galactose & G/D & + & $\mathrm{sh}$ & sh \\
\hline 905 & $\begin{array}{c}\mathrm{C}-\mathrm{O}-\mathrm{SO}_{3} \text { on } \mathrm{C}_{2} \text { of } \\
\text { 3,6-anhydrogalactose }\end{array}$ & DA2S & sh & $\mathrm{sh}$ & sh \\
\hline 930 & $\begin{array}{c}\text { C-O of 3,6-anhydrogalactose } \\
\text { (agar/carrageenan) }\end{array}$ & (DA) & + & + & sh \\
\hline $970-975$ & Galactose & G/D & + & + & - \\
\hline 1012 & Sulfated esters & $\mathrm{S}=\mathrm{O}$ & + & + & + \\
\hline 1070 & $\mathrm{C}-\mathrm{O}$ of 3,6-anhydrogalactose & $\mathrm{DA}$ & + & + & sh \\
\hline 1100 & Sulfated esters & $\mathrm{S}=\mathrm{O}$ & + & + & + \\
\hline $1240-1260$ & Sulfated esters & $\mathrm{S}=\mathrm{O}$ & + & + & + \\
\hline
\end{tabular}

Sh-shoulder (where the peak shows intensity but not enough to be designated a peak because of the surrounding peak intensities). 


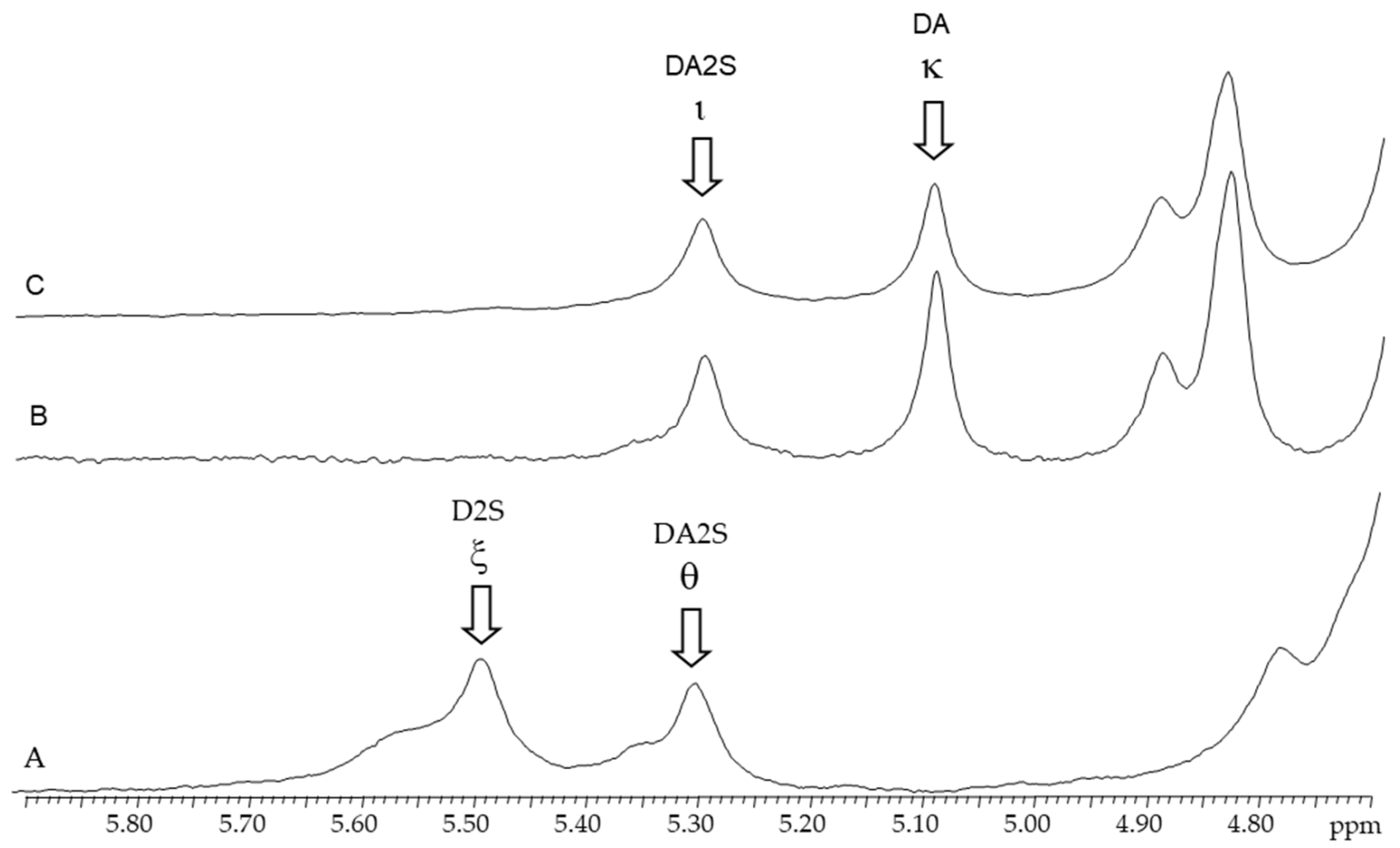

Figure 3. ${ }^{1} \mathrm{H}-\mathrm{NMR}$ spectra of carrageenans extracted from Chondracanthus teedei var. lusitanicus: A (tetrasporophyte). B (female gametophyte), C (male gametophyte).

\subsection{2. ${ }^{1} \mathrm{H}-\mathrm{RMN}$}

The anomeric protons zone of the ${ }^{1} \mathrm{H}-\mathrm{NMR}$ (Figure 3) spectra of native and alkalimodified carrageenan's from $C$. teedei var. lusitanicus female and male gametophytes revealed two strong signals at $5.11 \mathrm{ppm}$ and $5.32 \mathrm{ppm}$, respectively. The anomeric protons of 3,6-anhydro- $\alpha$-D-galactose (DA; kappa-carrageenan) and 2-sulfated 3,6-anhydro- $\alpha$ D-galactose (DA2S; iota-carrageenan) are represented by these signals. A weaker signal with a chemical shift of $5.37 \mathrm{ppm}$ was detected in the spectrum of the alkalineextracted female gametophyte sample, in addition to the carrageenan signals. This signal has been attributed to floridean starch, a common and natural contaminant found in carrageenan samples [32-35].

\subsection{3. ${ }^{13} \mathrm{C}-\mathrm{RMN}$}

The anomeric region of the ${ }^{13} \mathrm{C}-\mathrm{NMR}$ spectra of alkaline-extracted carrageenan (female and male gametophytes) contains three significant peaks (Figure 4B,C): $102.5 \mathrm{ppm}$ corresponds to anomeric carbon of $\beta$-D-galactose-4-sulfate residues (G4S) found in both kappa- and iota carrageenans; $95.3 \mathrm{ppm}$ corresponds to anomeric carbon of 3-6-anhydrogalactose (DA) in kappa-carrageenan; and $92.1 \mathrm{ppm}$ corresponds to anomeric carbon of anhydro-galactose-2-sulfate (DA2S) [32,34-36].

Figure $4 \mathrm{~T}$ show signals at 103.3 and $92.8 \mathrm{ppm}, 100.4$ and $95.7 \mathrm{ppm}$ that might be ascribed to the anomeric carbons of $x i$ and theta-carrageenan, respectively, in the ${ }^{13} \mathrm{C}-\mathrm{NMR}$ spectra of native and alkaline-extracted carrageenan from tetrasporophytes [37,38]. 

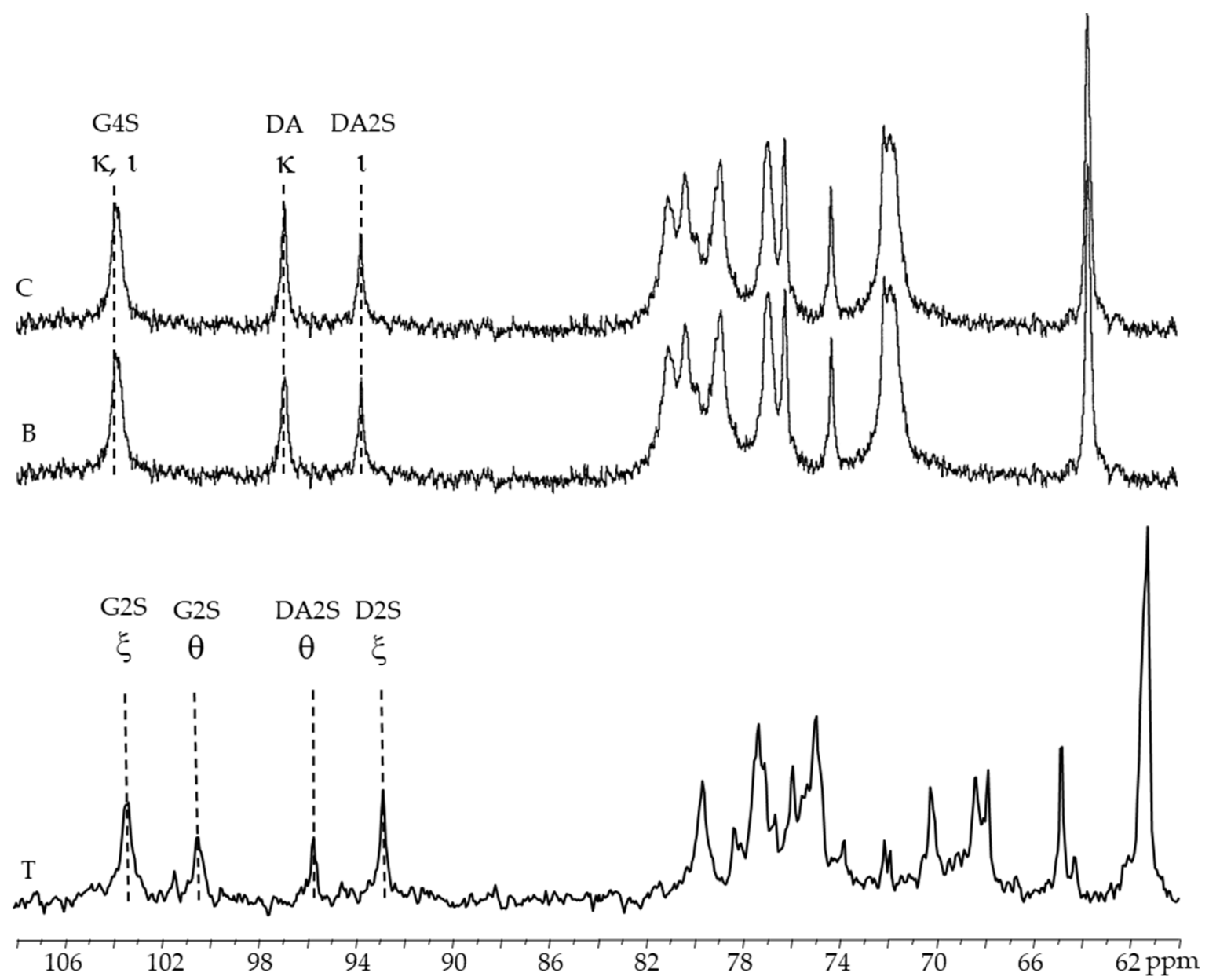

Figure 4. ${ }^{13} \mathrm{C}-\mathrm{NMR}$ spectra of carrageenans extracted from Chondracanthus teedei var. lusitanicus: $\mathbf{T}$ (tetrasporophyte). B (male gametophyte), C (female gametophyte-alkaline extraction).

\section{Discussion}

Among the algal phyla or classes, Chlorophyta (green), Phaeophyceae (brown) and Rhodophyta (red), the red seaweeds phyla contain the largest number of species [23]. Hereby, it is highlighted the nutraceutical potential that this phylum/class represents [39]. Seaweeds have been seen as a feedstock for bioactive molecules that can be incorporated in the daily diet as a supplement in order to promote human health, thus being considered nutraceutical food products [40].

The incorporation of the red seaweed Chondracanthus teedei in the daily diet has been recorded in some coastal areas of Southern Europe [41]. In some other parts of the globe, C. teedei revealed to be a potential food supplement with nutraceutical potential: so why not C. teedei var. lusitanicus? For instance, in Brazil, the dried biomass of C. teedei (at $45^{\circ} \mathrm{C}$ for $48 \mathrm{~h}$ ) revealed to be constituted by $14.66 \%$ of protein, $2.21 \%$ of fibers, $1.82 \%$ of total lipids, a mineral content of $28.68 \%$ and a moisture content of $86.73 \%$ [42]. A study conducted with C. teedei were, in overall, higher than those recorded in the current research for $C$. teedei var. lusitanicus, which may be attributable to differences in geographical harvesting sites, different physical-chemical parameters of the seawater, abiotic and biotic factors interaction, or even differences in seaweed processing, such as the drying process [43-45].

Previous findings already showed that the biochemical characterization of $C$. teedei can vary within the geographical area and the harvest season [46], particularly the nitrogen content, which suffers a decrease during the summer and autumn [21]. Indeed, several factors can influence nutrient uptake (particularly nitrogen and phosphorus), such as light, temperature, hydrodynamics, desiccation, and salinity [47,48]. In fact, researchers found 
that C. teedei var. lusitanicus harvested at Cabo Mondego (Figueira da Foz) in the summer of 2019 showed a lower protein content $\left(0.2 \mathrm{~g} 100 \mathrm{~g}^{-1} \mathrm{DW}\right)$ [49], which may be due to the different seaweed processing, particularly the drying process [50]. Because seaweeds have a low lipid content, they are considered a low-fat food [51]. Furthermore, it was discovered that the lipid profile of this seaweed can change substantially in terms of both qualitative and quantitative variation depending on its life cycle phase [52,53].

Within the threshold set by the competent authorities, the daily reference intakes of minerals and trace elements established by the European Parliament and the Council of European Union, as well as the recommended dietary allowances and adequate intakes established by the United States of America, C. teedei var. lusitanicus represents an adequate mineral source (namely of nitrogen, phosphorus, calcium, and magnesium) [54,55]. However, according to these results, a $100 \mathrm{~g}$ portion of this seaweed can in fact exceed the recommended dietary allowance and the adequate intake trace elements, particularly iron (0.014 g-EU; $0.008 \mathrm{~g}$-USA), copper (0.001 g-EU; $0.0009 \mathrm{~g}-\mathrm{USA}$ ), zinc (0.01 g-EU; $0.011 \mathrm{~g}$-USA) and manganese (0.002 g-EU; $0.0023 \mathrm{~g}-\mathrm{USA})$ [54,55]. Thus, the recommended intake is about $7 \mathrm{~g}$ (DW) of this seaweed species per day, due to the high content of these micronutrients. Particularly the iron content, which only $7 \mathrm{~g}$ of DW seaweed are near $9.15 \%$ of the iron daily intake (Table 1). This is consistent with the literature, which states that the maximum amount of dried seaweeds that may be consumed with favorable effects for human health is roughly $7 \mathrm{~g}$, after which the normal function of cell mechanisms can be directly impacted $[14,56]$.

The supply of macrominerals, such as calcium, magnesium, phosphorus, sodium, and potassium are required in larger amounts and needed for the proper functioning of the human body [17].

For instance, calcium is essential for several vital functions, since this mineral is a structural component of bones and teeth, cell membrane, and it is involved in neuromuscular activity, endocrine secretory function, and blood coagulation [57]. For this reason, the lack of this mineral can be reflected on low bone density, which could lead to the development of osteoporosis [57].

The lack of phosphorus can lead to the deterioration of mental function and in severe cases the patients can develop osteomalacia [57,58]. This happens because phosphorus is involved on regulatory processes, such as energy metabolism, $\mathrm{pH}$ maintenance, glycolysis, muscle, and nerve function, but is also a structural element on bone and cell membrane synthesis [57]. While sodium, as an electrolyte, has a regulatory role on the human body, regulating the water distribution, and being involved on the active transport of molecules through the cellular membrane $[59,60]$. For this reason, a diet poor in sodium can lead to dehydration by reduction of the body fluid volume $[59,60]$.

Additionally, magnesium is a key player for human cells as cofactor for more than 300 enzymes that regulates various biochemical processes in the human body, including protein synthesis, muscle and nerve function, blood glucose control, and blood pressure regulation [61,62]. Furthermore, $69 \mathrm{~g}$ of spinach or $105 \mathrm{~g}$ of kale contains the same magnesium content as this seaweed [63].

Potassium is one of the major intracellular cations, present in all human body cells because their inherent requirement for the cell homeostasis, as intracellular fluid regulator (osmosis process) and to intermediate the transmembrane electrochemical gradients (nervous signaling pathways and muscular function) $[59,64]$. Additionally, potassium helps to maintain the extracellular fluids, such as the plasma and blood $[59,65]$. This seaweed DRI is similar to $17.60 \mathrm{~g}$ of beet greens or $34.33 \mathrm{~g}$ of spinach [66].

As it shown in Tables 1 and 2, this seaweed is also a rich supply of microminerals: iron, manganese, copper and zinc, as well as dietary fibers and protein, displaying a strong nutraceutical source of key elements and compounds for human welfare [1].

Only $7 \mathrm{~g}$ DW of $C$. teedei var. lusitanicus contains the same amount of iron as $226 \mathrm{~g}$ of broccoli or potato [67], this is significant since iron is required for the metabolism of many human proteins, including enzymes and hemoglobin (responsible for oxygen and carbon 
dioxide transportation system) [68]. Furthermore, disorders caused by a shortage of iron (e.g., anemia) can be alleviated by iron supplementation in the daily diet [69].

The manganese content of $C$. teedei var. lusitanicus is equivalent to $8.4 \mathrm{~g}$ sweet potato or $7.6 \mathrm{~g}$ brown rice [70]. Manganese is an important cofactor for enzymes such as manganese superoxide dismutase, arginase, and pyruvate carboxylase [71,72]. Furthermore, this mineral is involved in a variety of metabolic processes, such as amino acid, cholesterol, glucose, and carbohydrate metabolisms. Additionally, manganese is involved in the scavenging of reactive oxygen species, bone formation, reproduction, and immunological response [73-75].

Just $7 \mathrm{~g}$ of this seaweed contains the same amount of copper as $7.6 \mathrm{~g}$ of sweet potato or $0.95 \mathrm{~g}$ of sesame seeds [76], being a necessary micronutrient due to its involvement in numerous biological processes such as antioxidant defense, neuropeptide production and immunological function $[77,78]$.

Zinc is a critical microelement that plays a regulatory and structural role in cell membrane stabilization, and only $7 \mathrm{~g}$ of this seaweed can provide the same amount of zinc as $12.9 \mathrm{~g}$ of Shiitake Mushrooms or $21 \mathrm{~g}$ of spinach [79].

Although some minerals are beneficial at low concentrations, they are extremely dangerous at medium concentrations, even causing human mortality. As a result, in order to attain the greatest advantage, this seaweed must be ingested in small doses, as indicated, making it a food supplement containing essential minerals with nutraceutical potential for human health [1].

The fiber level of $7 \mathrm{~g}$ of $C$. teedei var. lusitanicus is equivalent to $6 \mathrm{~g}$ of broccoli or $4 \mathrm{~g}$ of sweet potato [67]. The fiber in this seaweed is primarily carrageenan [25], and the key benefits are that it is digestible and swells in aqueous solution. As a result, carrageenan increases satiety and weight loss by decreasing stomach discharge and so providing improved glycemic control (reducing hyperglycemia-related illnesses). Furthermore, fibers have a favorable impact on the microbiome and gut transit in the gastrointestinal system [80].

Proteins are the fundamental building blocks of human cells, as well as the precursors of enzymes, antibodies, and hormones [81]. Hence, it is highlighted that the protein content in $7 \mathrm{~g}$ of the studied seaweed can replace $37 \mathrm{~g}$ of asparagus or $29 \mathrm{~g}$ of broccoli in a meal [67].

Carbohydrates are unique to each taxonomic group of seaweeds; and are also the major components of seaweeds biomass, which the human digestive system does not digest (acting as dietary fibers) [1]. However, seaweeds contain monosaccharides that despite having a low proportion, provide energy to human cells, to work and sustain their metabolism and regular functioning [1].

This nutritional comparative analysis highlights the quality of $C$. teedei var. lusitanicus as a nutritious food source, which has a potential to be used as a food supplement to enrich the deficiency of several macro and micronutrients in a typical diet. This seaweed can also be used as a food nutrient source for people that are living in developing countries as well as an alternative source of several minerals required for human cell homeostasis [82].

Important bioactive compounds that must be present in the human diet, such as proteins, lipids, carbohydrates, and minerals, are usually acquired through the vegetable consumption. Nevertheless, our results show that only $7 \mathrm{~g}(\mathrm{DW})$ or $50 \mathrm{~g}(\mathrm{FW})$ of $\mathrm{C}$. teedei var. lusitanicus can contribute to a healthy diet than higher amounts of vegetables. Hence, it is highlighted the nutraceutical potential of this unexploited marine resource.

Although the nutritional and mineral profiles of this seaweed are consistent across all life cycles, the polysaccharide profile differs from gametophytes to the tetrasporophyte [22].

According to Pereira (2004) [83], the carrageenan extraction yield of C. teedei var. lusitanicus (female and male gametophyte, tetrasporophyte) is consistent, even the sampling site was the same in both studies.

Regarding the spectroscopic analysis, it revealed that the two phases of the life cycle of C. teedei var. lusitanicus showed similar variation, which was also found in other Chondracanthus genus species [84]: carrageenans of the kappa family are produced by the gametophyte 
stages (hybrid kappa/iota/mu/nu carrageenan), whereas carrageenans of the lambda family are produced by the tetrasporophyte stages (hybrid xi/theta-carrageenan).

The male gametophyte of $C$. teedei var. lusitanicus appears to possess a similar phycocolloid to the female gametophytes, based on the FTIR-ATR, ${ }^{1} \mathrm{H}$ - and ${ }^{13} \mathrm{C}-\mathrm{NMR}$ spectra of its carrageenans. Even though both thalli formed a kappa/iota hybrid carrageenan (Table 1), the male thalli had equal levels of kappa and iota-fraction, but the kappa-fraction was slightly dominant in female gametophytes.

Regarding the male and female gametophytes alkaline-extracted carrageenan, our findings are similar to those of Pereira et al. (2004) and Zinoun et al. (1993) [32,85]. The existence of xi-carrageenan is indicated by the FTIR spectra of tetrasporic samples of C. teedei, which display stronger peaks at $830 \mathrm{~cm}^{-1}$, but less absorption at $820 \mathrm{~cm}^{-1}$. The presence of a hybrid xi/theta-carrageenan was confirmed by the ${ }^{13} \mathrm{C}$-NMR spectra, despite the ${ }^{1} \mathrm{H}-\mathrm{NMR}$ spectra not being conclusive (results not reported).

Following the minerals, polysaccharides, initially identified as carbohydrates, were found to contribute for a significant portion of the DW of the seaweed biomass. However, most of these polysaccharides are carrageenans, known as dietary fiber, due to its inability to break the high weight molecule in the human digestive tract.

Because of the negative effects that can occur if the cumulative dosage of seaweed polysaccharides (and particularly their lower-molecular-weight oligomers) exceeds the limit of $25 \mathrm{~g} /$ day, the diversity of seaweed polysaccharides (and particularly their lowermolecular-weight oligomers) needs to be quantified [86,87]. The recommended biomass intake of $C$. teedei var. lusitanicus ranges between 11 and $7 \%$ of this value, indicating that it is a supplement for human food intake that promotes human wellness.

Polysaccharides from seaweed with a high molecular weight are typically thought to be desirable dietary fibers. These are considered to be essential contributors in human health and illness prevention in certain applications [88]. These advantages are enlarged because the gut microbiome interacts with the host at both the intestinal and systemic levels, resulting in balance between the host and the microbiota. Food intake can have a beneficial or negative impact on the microflora balance, resulting in immunological, physiological, metabolic, and even psychological effects [88,89].

In addition to their biological properties, seaweed polysaccharides also have innate features that are very important for intestinal health; these include the viscosity and the high potential for water-binding activity, which adjusts the transit time of food through the gut. Such properties are demonstrated to promote satiety and weight loss; additionally, they delay gastric discharge, therefore promoting glycemic control (i.e., minimizing the incidence of diabetes). In the intestinal tract, all seaweed-derived polysaccharides are reported to enhance gut transit, maintaining regular stool volume, and promote beneficial alterations to the composition of the microbiome [14]. These advantages add up to improved metabolization of volatile fatty acids (VFAs), which are also known as short chain fatty acids (SCFAs), by members of the microflora, promoting positive effects in the gastrointestinal system, and thus improving cardiometabolic, immune, bone, and health conditions [14,90-92].

Due to the polysaccharides fermentation in the intestinal tract, reducing the microflora/bile salt hydrolase activity, anti-obesity effects have been identified as one of the most advantageous properties of seaweed polysaccharides for human ingestion, which is one theory for this observed effect [93-95]. In this case, in vitro experiments revealed that the microbiome composition changed to an enhanced condition, including populations of Bifidobacterium, Bacteroides, Lactobacillus, Roseburia, Parasutterella, Fusicatenibacter, Coprococcus and Fecalibacterium colonies [93-95].

Carrageenans are one of the most bioactive polysaccharides found in seaweeds; their chemical structure allows them to form hydrogels, allowing them to be employed as antiviral and antibacterial components in a myriad of product formulations $[96,97]$. Given the excellent levels of safety, efficacy, and biocompatibility, as well as the fact that they are biodegradable and non-toxic, there are strong reasons to use these compounds [98]. 
Carrageenan has also been used as a traditional medicine to treat coughs and the common cold, according to ancient documents, hence in vitro and in vivo experiments using animal models have corroborated this ethno-botanical information. The actions of carrageenans on blood platelet aggregation are principally responsible for this capability (i.e., anticoagulant activity) $[99,100]$. Other carrageenan bioactivities, such as anti-tumor, anti-viral, and immunomodulation, have been proven and are commercially exploited [101,102]. In the case of herpes simplex virus types 1 and 2, HIV-1 and human rhinovirus, the carrageenan antiviral system operates by keeping virus particles far from the cell, which is considered to be an encouraging outcome $[103,104]$.

Furthermore, the inclusion of this red seaweed species in the human diet contributes as a flavor enhancer in soups, salads, or seafood, imparting a pleasant mushroom scent [105]. However, the existence of some harmful volatile chemicals, such as bromoform, implies that the inclusion of this fresh seaweed into the human diet should be done with caution $[105,106]$. Although the application of the Asparagopsis sp. to feed cattle with the objective to reduce the methane, the bromoform molecules are a main target to understand their behavior during the seaweed processing [107]. Furthermore, it is supported that the seaweed drying and other type of processing (such as washing or cooking) reduce the bromoform and other volatile (such as iodine) compounds concentration in the seaweeds, mainly the solar drying and seaweed dehydration [108-111]. Only, the freeze drying maintain the same level of bromoform compounds in the dried seaweeds [108].

\section{Materials and Methods}

\subsection{Seaweed Harvesting and Preparation}

On 27 May 2020, the red seaweed Chondracanthus teedei var. lusitanicus was harvested in the Portuguese seashore of Buarcos Bay at Figueira da Foz (40.165867, -8.885556). Afterwards seaweeds were placed in plastic bags inside a coolbox and transported to the laboratory where were frozen at $-20^{\circ} \mathrm{C}$ for prior use. Some days later, the seaweeds were washed with filtered seawater to remove sand, epiphytes and other detritus from the seaweed biomass. Afterwards, the seaweed biomass was washed with distilled water to remove the salt content from the seawater, placed in plastic trays, and dried in an air-forced oven (Raypa DAF-135, R. Espinar S.L., Barcelona, Spain) at $60{ }^{\circ} \mathrm{C}$ during $48 \mathrm{~h}$. Dried biological samples were milled $(<1 \mathrm{~cm})$ with a commercial grinder (Taurus aromatic, Oliana, Spain) and stored in sterile flasks in a dark and dry place (54\% humidity) at room temperature $\left(23^{\circ} \mathrm{C}\right)$.

\subsection{Mineral and Trace Element Characterization}

With the ashes obtained, the mineral content was analyzed through dry mineralization and assessed using flame atomic absorption spectrometry (PerkinElmer PinAAcle $900 \mathrm{~T}$, Waltham, MA, USA) [112]. Phosphorus analysis was performed by spectrophotometry (PG instruments T80+ UV/VIS spectrophotometer, Leicestershire, United Kingdom) [113].

For this analysis, we performed an acid digestion with nitric acid $65 \%(\mathrm{~m} / \mathrm{v})$, in a water bath at $100{ }^{\circ} \mathrm{C}$ around $30 \mathrm{~min}$. Finally, the samples were filtrated for a volumetric flask and the volume adjusted with distilled water. After the necessary dilutions (1:10, $1: 100$ and 1:500) the analysis was carried out on the atomic absorption spectrophotometer equipped with the cathode corresponding to each element.

\subsection{Nutritional Profile}

\subsubsection{Moisture and Ashes Content}

According to the international standard method 930.04 of Official Methods of Analysis of AOAC International [114], the moisture content was assessed through the fresh weighting of the algal samples and, then, after oven-drying (Memmert, Büchenbach, Germany) at $60{ }^{\circ} \mathrm{C}$ during $48 \mathrm{~h}$. Afterwards, the samples were milled $(<1 \mathrm{~mm})$ and, approximately, $2 \mathrm{~g}$ of each sample was placed in crucibles and dried at $105{ }^{\circ} \mathrm{C}$ for $2 \mathrm{~h}$. Then, the samples were placed in a desiccator until constant weight for being again weighted, 
in order to calculate the moisture content. In accordance with the AOAC method 930.05, the dried samples at $105{ }^{\circ} \mathrm{C}$ were placed in an incineration muffle during $2 \mathrm{~h}$ at $550{ }^{\circ} \mathrm{C}$ (Induzir, Batalha, Portugal) and further cooled in a desiccator and weighted to assess the ashes amount.

\subsubsection{Crude Lipids}

The total lipids content was gravimetrically quantified following a continuous extraction process with diethyl ether in a Soxhlet apparatus (Behr Labor-Technik GmbH, Düsseldorf, Germany), as it follows the international standard AOAC method 930.09 [114]. The distillation flasks were previously dried at $105^{\circ} \mathrm{C}$ for $2 \mathrm{~h}$, cooled in a desiccator and weighted in an analytical scale (Sartorix, Göttingen, Germany). Afterwards, the distillation flasks were filled (2/3 of their capacity) with diethyl ether (Panreac, Chicago, IL, USA). Then, approximately $2 \mathrm{~g}$ of the algal samples were packed in filter paper and placed into the thimble. After $16 \mathrm{~h}$ of extraction, all the solvent was collected and evaporated (BÜCHI Labortechnik AG, Flawil, Switzerland). The distillation flasks were then dried at $105{ }^{\circ} \mathrm{C}$ for $2 \mathrm{~h}$ and weighted when cooled down.

\subsubsection{Total Nitrogen/Protein}

The total nitrogen/protein content was determined by Kjeldhal method (AOAC method 978.04) [114], while it was used 5 as a protein conversion factor [115]. In a Kjeldhal tube, was added approximately $0.5 \mathrm{~g}$ of the previously dried algal sample, and then it was added a selenium catalyst (PanReac AppliChem, Darmstadt, Germany) and $12 \mathrm{~mL}$ of sulfuric acid (Chem-Lab NV, Zedelgem, Belgium). The tubes were then placed into the Kjeldhal digester (VELP Scientifica, Usmate Velate MB, Italy) at $400{ }^{\circ} \mathrm{C}$ for $2 \mathrm{~h}$. The samples could cool in the fume cupboard, and it was added $50 \mathrm{~mL}$ of distilled water in each tube and putted into the Kjeldhal distiller. Concurrently, it was placed $30 \mathrm{~mL}$ of boric acid (Chem-Lab NV, Zedelgem, Belgium) in an Erlenmeyer (one for sample), being further placed into the Kjeldhal distiller as well (VELP Scientifica, Usmate Velate MB, Italy). To the Kjeldhal tube was added $50 \mathrm{~mL}$ of distilled water and $50 \mathrm{~mL}$ of sodium hydroxide $(\mathrm{NaOH})$ at $40 \%(\mathrm{~m} / \mathrm{v})$ (JMGS-José Manuel Gomes dos Santos, Odivelas, Portugal). The distilled solution was collected and titrated with chloridric acid $(\mathrm{HCl}) 0.1 \mathrm{M}$ (Chem-Lab NV, Zedelgem, Belgium).

\subsubsection{Crude Fiber and Total Carbohydrates/Nitrogen-Free Extractives}

According to the standard method 930.10 of AOAC [114], the crude fiber was analyzed through the weighting of $2 \mathrm{~g}$ from the algal samples, previously oven dried (Memmert, Germany) at $105^{\circ} \mathrm{C}$ for $2 \mathrm{~h}$ and placed in a $600 \mathrm{~mL}$ goblet. It was then added $200 \mathrm{~mL}$ of sulfuric acid $\left(\mathrm{H}_{2} \mathrm{SO}_{4}\right) 12.5 \mathrm{~g} / \mathrm{L}$ (Chem-Lab NV, Belgium) and the samples were placed in a fiber analyzer (Labconco Corporation, Kansas City, MO, USA) for 30 min. After this procedure, the samples were filtered with a filter crucible G2 under vacuum (General Electric, Boston, MA, USA). The residue was then placed into the goblet with $250 \mathrm{~mL}$ of sodium hydroxide (NaOH) 12.5 g/L (JMGS-José Manuel Gomes dos Santos, Odivelas, Portugal) and set into the fiber analyzer for more $30 \mathrm{~min}$. With the same filter crucible G2, the samples were again vacuum filtered and dried at $130{ }^{\circ} \mathrm{C}$ for $2 \mathrm{~h}$. After the samples were cooled down in a desiccator, they were weighted in an analytical scale (Sartorix, Germany) and placed into an incineration muffle at $550{ }^{\circ} \mathrm{C}$ (Induzir, Batalha, Portugal) for $2 \mathrm{~h}$. Finally, the samples could cool down and were weighted to calculate the crude fiber. Nitrogen-free extractives are the difference for 100 of the remaining constituents (moisture, lipids, protein, crude fiber and ash), while the total carbohydrates, corresponds approximately to the difference between 100 and the sum of the moisture, ash, lipids and protein. 


\subsection{Polyssacharides Characterization}

Due to carrageenan type variation, the red seaweed C. teedei var. lusitanicus was separated into phases based on their life cycle using a binocular magnifying glass (Kern \& Sohn $\mathrm{GmbH}$, Balingen, Germany).

\subsubsection{Carrageenan Extraction}

The extraction of carrageenan was carried out in accordance with the method reported by Pereira and van de Velde (2011) [116]. Before extraction, the milled seaweed (1 g) was pre-treated with an acetone (Fisher Chemicals, Portugal): methanol (VWR Prolabo Chemical, Portugal) (1:1) solution in a final concentration of $1 \%(\mathrm{~m} / \mathrm{v})$ (final volume: $100 \mathrm{~mL} ; 50 \mathrm{~mL}$ acetone: $50 \mathrm{~mL}$ methanol) for $16 \mathrm{~h}$, at $4{ }^{\circ} \mathrm{C}$, to remove the organic-soluble fraction. The liquid solution was decanted, and the seaweed residues obtained were dried in an air-forced oven (Raypa DAF-135, R. Espinar S.L., Barcelona, Spain) at $60^{\circ} \mathrm{C}$ before the extraction.

The dried samples were placed in $150 \mathrm{~mL}$ of $\mathrm{NaOH}$ (Applichem Panreac, Chicago, IL, USA) (1 M) (1 g of initial seaweed: $150 \mathrm{~mL}$ of $\mathrm{NaOH}$ solution) in a hot water bath system (GFL 1003, GFL, Burgwedel, Germany), at $85-90^{\circ} \mathrm{C}$, for $3 \mathrm{~h}$. The solutions were hot filtered, under vacuum (Laborport N820, Lisbon, Portugal) through a cloth filter supported in a Buchner funnel. After that, the extract was again filtered under vacuum with a Goosh 2 silica funnel. The extract was evaporated (rotary evaporator model: 2,600,000, Witeg, Germany) under vacuum to one-third of the initial volume $(50 \mathrm{~mL})$. The carrageenan was precipitated by adding twice its volume of $96 \%$ ethanol (José Manuel Gomes dos Santos, Portugal) $(100 \mathrm{~mL})$. The carrageenan precipitated was washed with ethanol $96 \%$, $48 \mathrm{~h}$ at $4{ }^{\circ} \mathrm{C}$ before dry in an air force oven $\left(60^{\circ} \mathrm{C}, 48 \mathrm{~h}\right.$ ) (Raypa DAF-135, R. Espinar S.L., Barcelona, Spain).

\subsubsection{FTIR-ATR Characterization}

The Fourier Transform Infrared Spectroscopy-Attenuated Total Reflection (FTIRATR) examination is a methodology of infrared spectroscopy that is frequently used to investigate and characterize carbohydrates found in seaweeds (among other chemicals) and is based on the procedure outlined by Pereira, Gheda and Ribeiro-Claro (2013) [30].

The dried polysaccharide samples from the previous polysaccharide extraction phases were powdered using a commercial mill and subjected to direct examination without further preparation for FTIR-ATR analysis. This technique requires only a dried milled $(<1 \mathrm{~mm})$ sample to be evaluated.

FTIR-ATR spectra were recorded on an Perkin Elmer Spectrum 400 spectrometer (Waltham, MA, USA), with no need for sample preparation, since these assays only required dried samples [31]. All spectra are the average of two independent measurements from 650 to $1500 \mathrm{~cm}^{-1}$ with 128 scans, each at a resolution of $2 \mathrm{~cm}^{-1}$.

\subsection{3. ${ }^{1} \mathrm{H}-\mathrm{NMR}$ Characterization}

${ }^{1} \mathrm{H}-\mathrm{NMR}$ spectra were made on a Bruker AMX600 spectrometer operating at $500.13 \mathrm{MHz}$ at $65^{\circ} \mathrm{C}$. Typically, 64 scans were recorded with an interpulse delay of $5 \mathrm{~s}$ (T1 values for the resonance of the anomeric protons of $\mathrm{k}$ - and $\mathrm{l}$-carrageenan are shorter than $1.5 \mathrm{~s})$. Sample preparation for the ${ }^{1} \mathrm{H}-\mathrm{NMR}$ experiments involved dissolving the carrageenan sample (5 mg mL ${ }^{-1}$ ) at $80^{\circ} \mathrm{C}$ in D2O containing 1 mMTSP (3-(trimethylsilyl) propionic-2,2,3,3-d4 acid sodium salt) and $20 \mathrm{mM} \mathrm{Na}_{2} \mathrm{HPO}_{4}$, followed by sonication (Branson 2510) for three periods of $1 \mathrm{~h}$. Chemical shifts $(\delta)$ are referred to internal TSP standard $(\delta=0 \mathrm{ppm}$ for $1 \mathrm{H})$ according to Knutsen and Grasdalen (1987) [33]. The chemical shift data described by Van de Velde et al. (2002a) [34] were used to assign the ${ }^{1} \mathrm{H}-\mathrm{NMR}$ spectra.

\subsection{4. ${ }^{13} \mathrm{C}$-NMR Characterization}

Female and male gametophytes alkaline-extracted carrageenans ${ }^{13} \mathrm{C}-\mathrm{NMR}$ spectra were obtained on a Varian Unity 500 spectrometer at $125.69 \mathrm{MHz}$. Samples $\left(15 / 20 \mathrm{mg} \mathrm{mL}^{-1}\right)$ were 
dissolved in $\mathrm{D}_{2} \mathrm{O}$ and the spectra were recorded at $80^{\circ} \mathrm{C}, 10.000$ accumulations, pulse $15 \mu \mathrm{s}$, acquisition time $3 \mathrm{~s}$ and relaxation delay $5 \mathrm{~s} .{ }^{13} \mathrm{C}-\mathrm{NMR}$ spectra of tetrasporic carrageenans were recorded on a Bruker AMX500 spectrometer operating at $125.76 \mathrm{MHz}$, as described in the literature [34,35].

The sample preparation was as follows: a solution of $5 \mathrm{mg} \mathrm{mL}^{-1}$ carrageenan in $\mathrm{H}_{2} \mathrm{O}$ was prepared at $80^{\circ} \mathrm{C}$. This solution was sonicated for three periods of $30 \mathrm{~min}$ in melting ice (Heat Systems XL 2020 sonicator, $12 \mathrm{~mm}$ tip, power $475 \mathrm{~W}$, frequency $20 \mathrm{kHz}$ ); the solution was centrifuged at elevated temperature to remove insoluble material. The sonicated material was dialyzed against phosphate buffer $\left(20 \mathrm{mM} \mathrm{Na}_{2} \mathrm{HPO}_{4} ; 3\right.$ times $\left.2 \mathrm{~L}\right)$, water (1 time $2 \mathrm{~L}$ ) and lyophilized. A concentration of $70-100 \mathrm{mg} \mathrm{mL}^{-1}$ in $\mathrm{D}_{2} \mathrm{O}$ containing $20 \mathrm{mM} \mathrm{Na}_{2} \mathrm{HPO}_{4}$ and $30 \mathrm{mM}$ TSP, was used to dissolve the material. Chemical shifts ( $)$ were referred to an external TSP/DMSO standard $\left(\delta \mathrm{DMSO}=39.45 \mathrm{ppm}\right.$ for $\left.{ }^{13} \mathrm{C}\right)$, in accordance with Usov et al., (1980) [36]. The chemical shift data summarized by Van de Velde et al., (2002) [34] was used to assign the ${ }^{13}$ C-NMR spectra.

\section{Conclusions}

The chemical analysis of the red seaweed Chondracanthus teedei var. lusitanicus shows that this species has a favorable nutritional profile for human diet and may have some nutraceutical benefits in lowering several common fast food-related disorders (such as diabetes, obesity, or cardiovascular diseases).

Further research is needed on this seaweed, mainly to determine which growing techniques are more adequate to cultivate, and, in such conditions, to study the expected changes in its nutritional profile.

Finally, this red seaweed has nutraceutical potential that should be exploited as a food supplement, which even in low doses can improve human welfare.

On the other hand, this seaweed intake overdosage can have a negative influence on human health, mostly through an uncontrolled mineral intake and can have an impact on cell homeostasis. For this reason, to consider any seaweed proper for human consumption, its nutritional composition must be monitored regularly.

Author Contributions: Conceptualization, D.P., J.C., K.B. and L.P.; investigation, D.P., A.D., J.C. and S.R.; data curation, D.P., A.D., J.C. and S.R.; writing-original draft preparation, D.P., J.C. and A.D.; writing-review and editing, D.P., J.C., A.D., S.R., K.B. and L.P.; supervision, S.R., K.B. and L.P. All authors have read and agreed to the published version of the manuscript.

Funding: This work was financed by national funds through FCT (Foundation for Science and Technology), I. P., within the scope of the projects UIDB/04292/2020 (MARE, Marine and Environmental Sciences Center). João Cotas thanks to the European Regional Development Fund through the Interreg Atlantic Area Program, under the project NASPA (EAPA_451/2016).

Institutional Review Board Statement: Not applicable.

Data Availability Statement: Not applicable.

Acknowledgments: The authors would like to acknowledge the Artur Figueirinha for the FTIR-ATR spectra acquisition. João Cotas thanks to the European Regional Development Fund through the Interreg Atlantic Area Program, under the project NASPA (EAPA_451/2016).

Conflicts of Interest: The authors declare no conflict of interest.

\section{References}

1. Leandro, A.; Pacheco, D.; Cotas, J.; Marques, J.C.; Pereira, L.; Gonçalves, A.M.M. Seaweed's Bioactive Candidate Compounds to Food Industry and Global Food Security. Life 2020, 10, 140. [CrossRef] [PubMed]

2. García-Poza, S.; Leandro, A.; Cotas, C.; Cotas, J.; Marques, J.C.; Pereira, L.; Gonçalves, A.M.M. The Evolution Road of Seaweed Aquaculture: Cultivation Technologies and the Industry 4.0. Int. J. Environ. Res. Public Health 2020, 17, 6528. [CrossRef] [PubMed]

3. Denis, C.; Morançais, M.; Li, M.; Deniaud, E.; Gaudin, P.; Wielgosz-Collin, G.; Barnathan, G.; Jaouen, P.; Fleurence, J. Study of the chemical composition of edible red macroalgae Grateloupia turuturu from Brittany (France). Food Chem. 2010, 119, $913-917$. [CrossRef] 
4. Milinovic, J.; Mata, P.; Diniz, M.; Noronha, J.P. Umami taste in edible seaweeds: The current comprehension and perception. Int. J. Gastron. Food Sci. 2021, 23, 100301. [CrossRef]

5. Kılınç, B.; Cirik, S.; Turan, G.; Klnc, B.; Cirik, S.; Turan, G.; Tekogul, H.; Koru, E.; Kılınç, B.; Cirik, S.; et al. Seaweeds for Food and Industrial Applications. In Food Industry; Intechopen: London, UK, 2013; pp. 735-748. [CrossRef]

6. Fleurence, J. Seaweeds as Food. In Seaweed in Health and Disease Prevention; Elsevier: Amsterdam, The Netherlands, 2016; pp. 149-167, ISBN 9780128027936.

7. Love, R. Optimisation of the culture of the red algae Chondrachantus teedei. In Effects of Irradiance, Temperature, Salinity and Nutrient Enrichment; Facultad de ciencias del mar y ambientales, Universidad de Cádiz: Cadiz, Spain, 2018.

8. Fleurence, J. Seaweed proteins: Biochemical, nutritional aspects and potential uses. Trends Food Sci. Technol. 1999, 10, 25-28. [CrossRef]

9. Pereira, L. A review of the nutrient composition of selected edible seaweeds. In Seaweed: Ecology, Nutrient Composition and Medicinal Uses; Nova Science Publishers: Hauppauge, NY, USA, 2011; ISBN 9781614708780.

10. Davis, G.D.J.; Vasanthi, A.H.R. Seaweed metabolite database (SWMD): A database of natural compounds from marine algae. Bioinformation 2011, 5, 361-364. [CrossRef]

11. Nunraksa, N.; Rattanasansri, S.; Praiboon, J.; Chirapart, A. Proximate composition and the production of fermentable sugars, levulinic acid, and HMF from Gracilaria fisheri and Gracilaria tenuistipitata cultivated in earthen ponds. J. Appl. Phycol. 2019, 31, 683-690. [CrossRef]

12. Ganesan, A.R.; Tiwari, U.; Rajauria, G. Seaweed nutraceuticals and their therapeutic role in disease prevention. Food Sci. Hum. Wellness 2019, 8, 252-263. [CrossRef]

13. Hannan, M.A.; Dash, R.; Haque, M.N.; Mohibbullah, M.; Sohag, A.A.M.; Rahman, M.A.; Uddin, M.J.; Alam, M.; Moon, I.S. Neuroprotective Potentials of Marine Algae and Their Bioactive Metabolites: Pharmacological Insights and Therapeutic Advances. Mar. Drugs 2020, 18, 347. [CrossRef]

14. Cherry, P.; O’Hara, C.; Magee, P.J.; McSorley, E.M.; Allsopp, P.J. Risks and benefits of consuming edible seaweeds. Nutr. Rev. 2019, 77, 307-329. [CrossRef]

15. Mišurcová, L.; Machů, L.; Orsavová, J. Seaweed Minerals as Nutraceuticals. In Advances in Food and Nutrition Research; Kim, S.-K., Ed.; Academic Press: Cambridge, MA, USA, 2011; pp. 371-390.

16. National Research Council (U.S.). Committee on Diet and Health. Diet and Health: Implications for Reducing Chronic Disease Risk/Committee on Diet and Health, Food and Nutrition Board, Commission on Life Sciences, National Research Council; National Academy Press: Washington, DC, USA, 1989; ISBN 0-309-03994-0.

17. Lamb, M.W.; Harden, M.L. Mineral Elements in Human Nutrition. In The Meaning of Human Nutrition; Lamb, M.W., Harden, M.L., Eds.; Elsevier: Amsterdam, The Netherlands, 1973; pp. 193-210.

18. Doley, J. Vitamins and Minerals in Older Adults. In Nutrition and Functional Foods for Healthy Aging; Watson, R.R., Ed.; Elsevier: Amsterdam, The Netherlands, 2017; pp. 125-137. ISBN 978-0-12-805376-8.

19. British Nutrition Foundation. Average Daily Intakes of Vitamins from Food Sources Only: \% Below the Lower Reference Nutrient Intake (LRNI), by Age and Sex. Available online: https://www.nutrition.org.uk/attachments/article/255/ LRNIvitaminsandminerals.pdf (accessed on 14 September 2021).

20. Bermejo, R.; Macías, M.; Cara, C.L.; Sánchez-García, J.; Hernández, I. Culture of Chondracanthus teedei and Gracilariopsis longissima in a traditional salina from southern Spain. J. Appl. Phycol. 2019, 31, 561-573. [CrossRef]

21. Bermejo, R.; Cara, C.L.; Macías, M.; Sánchez-García, J.; Hernández, I. Growth rates of Gracilariopsis longissima, Gracilaria bursapastoris and Chondracanthus teedei (Rhodophyta) cultured in ropes: Implication for N biomitigation in Cadiz Bay (Southern Spain). J. Appl. Phycol. 2020, 32, 1879-1891. [CrossRef]

22. Pereira, L.; Silva, P. A concise review of the red macroalgae Chondracanthus teedei (Mertens ex Roth) Kützing and Chondracanthus teedei var. lusitanicus (J.E. De Mesquita Rodrigues) Bárbara \& Cremades. J. Appl. Phycol. 2021, 33, 111-131. [CrossRef]

23. Guiry, M.D.; Guiry, G.M. AlgaeBase. World-Wide Electronic Publication. Available online: https://www.algaebase.org (accessed on 23 July 2021).

24. Soares, F.; Fernandes, C.; Silva, P.; Pereira, L.; Gonçalves, T. Antifungal activity of carrageenan extracts from the red alga Chondracanthus teedei var. lusitanicus. J. Appl. Phycol. 2016, 28, 2991-2998. [CrossRef]

25. Pereira, L. (Ed.) Edible Seaweeds of the World; CRC Press: Boca Raton, FL, USA, 2016; ISBN 9780429154041.

26. Soares, F. Antifungal, Antibacterial and Antiviral Activity of Chondracanthus teedei var. Lusitanicus (Gigartinaceae, Rhodophyta). Master's Thesis, University of Coimbra, Coimbra, Portugal, 2015.

27. Cotas, J.; Pacheco, D.; Araujo, G.S.; Valado, A.; Critchley, A.T.; Pereira, L. On the Health Benefits vs. Risks of Seaweeds and Their Constituents: The Curious Case of the Polymer Paradigm. Mar. Drugs 2021, 19, 164. [CrossRef] [PubMed]

28. Pereira, L.; Mesquita, J.F. Carrageenophytes of occidental Portuguese coast: 1-spectroscopic analysis in eight carrageenophytes from Buarcos bay. Biomol. Eng. 2003, 20, 217-222. [CrossRef]

29. Pereira, L.; Amado, A.M.; Critchley, A.T.; van de Velde, F.; Ribeiro-Claro, P.J.A. Identification of selected seaweed polysaccharides (phycocolloids) by vibrational spectroscopy (FTIR-ATR and FT-Raman). Food Hydrocoll. 2009, 23, 1903-1909. [CrossRef]

30. Pereira, L.; Gheda, S.F.; Ribeiro-Claro, P.J.A. Analysis by Vibrational Spectroscopy of Seaweed Polysaccharides with Potential Use in Food, Pharmaceutical, and Cosmetic Industries. Int. J. Carbohydr. Chem. 2013, 2013, 537202. [CrossRef] 
31. Pereira, L.; Critchley, A.T.; Amado, A.M.; Ribeiro-Claro, P.J.A. A comparative analysis of phycocolloids produced by underutilized versus industrially utilized carrageenophytes (Gigartinales, Rhodophyta). J. Appl. Phycol. 2009, 21, 599-605. [CrossRef]

32. Pereira, L.; Mesquita, J.F. Population studies and carrageenan properties of Chondracanthus teedei var. lusitanicus (Gigartinaceae, Rhodophyta). J. Appl. Phycol. 2004, 16, 369-383. [CrossRef]

33. Knutsen, S.H.; Grasdalen, H. Characterization of Water-extractable Polysaccharides from Norwegian Furcellaria lumbricalis (Huds.) Lamour. (Gigartinales, Rhodophyceae) by IR and NMR Spectroscopy. Bot. Mar. 1987, 30, 497-505. [CrossRef]

34. Van de Velde, F.; Knutsen, S.H.; Usov, A.I.; Rollema, H.S.; Cerezo, A.S. $1 \mathrm{H}$ and 13C high resolution NMR spectroscopy of carrageenans: Application in research and industry. Trends Food Sci. Technol. 2002, 13, 73-92. [CrossRef]

35. Van de Velde, F.; Rollema, H.S.; Grinberg, N.V.; Burova, T.V.; Grinberg, V.Y.; Tromp, R.H. Coil-helix transition of?-carrageenan as a function of chain regularity. Biopolymers 2002, 65, 299-312. [CrossRef] [PubMed]

36. Usov, A.I.; Yarotsky, S.V.; Shashkov, A.S. 13C-NMR spectroscopy of red algal galactans. Biopolymers 1980, 19, 977-990. [CrossRef]

37. Falshaw, R.; Furneaux, R.H. Carrageenan from the tetrasporic stage of Gigartina decipiens (Gigartinaceae, Rhodophyta). Carbohydr. Res. 1994, 252, 171-182. [CrossRef]

38. Falshaw, R.; Furneaux, R.H. Carrageenans from the tetrasporic stages of Gigartina clavifera and Gigartina alveata (Gigartinaceae, Rhodophyta). Carbohydr. Res. 1995, 276, 155-165. [CrossRef]

39. Torres, P.; Nagai, A.; Teixeira, D.I.A.; Marinho-Soriano, E.; Chow, F.; dos Santos, D.Y.A.C. Brazilian native species of Gracilaria (Gracilariales, Rhodophyta) as a source of valuable compounds and as nutritional supplements. J. Appl. Phycol. 2019, 31, 3163-3173. [CrossRef]

40. Alwaleed, E.A. Biochemical Composition and Nutraceutical Perspectives Red Sea Seaweeds. Am. J. Appl. Sci. 2019, 16, 346-354. [CrossRef]

41. Palmieri, N.; Forleo, M.B. The potential of edible seaweed within the western diet. A segmentation of Italian consumers. Int. J. Gastron. Food Sci. 2020, 20, 100202. [CrossRef]

42. Menezes, B.S.; Coelho, M.S.; Meza, S.L.R.; Salas-Mellado, M.; Souza, M.R.A.Z. Macroalgal biomass as an additional ingredient of bread. Int. Food Res. J. 2015, 22, 812-817.

43. Zertuche-González, J.A.; Sandoval-Gil, J.M.; Rangel-Mendoza, L.K.; Gálvez-Palazuelos, A.I.; Guzmán-Calderón, J.M.; Yarish, C. Seasonal and interannual production of sea lettuce (Ulva sp.) in outdoor cultures based on commercial size ponds. J. World Aquac. Soc. 2021, 2021, 1-12. [CrossRef]

44. Stévant, P.; Ólafsdóttir, A.; Déléris, P.; Dumay, J.; Fleurence, J.; Ingadóttir, B.; Jónsdóttir, R.; Ragueneau, É; Rebours, C.; Rustad, T. Data on the sensory characteristics and chemical composition of the edible red seaweed dulse (Palmaria palmata) after dry and semi-dry storage. Data Brief 2020, 33, 106343. [CrossRef]

45. Britton, D.; Schmid, M.; Revill, A.T.; Virtue, P.; Nichols, P.D.; Hurd, C.L.; Mundy, C.N. Seasonal and site-specific variation in the nutritional quality of temperate seaweed assemblages: Implications for grazing invertebrates and the commercial exploitation of seaweeds. J. Appl. Phycol. 2021, 33, 603-616. [CrossRef]

46. Osman, M.E.H.; Abo-Shady, A.M.; Elshobary, M.E.; Abd El-Ghafar, M.O.; Abomohra, A.E.-F. Screening of seaweeds for sustainable biofuel recovery through sequential biodiesel and bioethanol production. Environ. Sci. Pollut. Res. 2020, 27, 32481-32493. [CrossRef] [PubMed]

47. Roleda, M.Y.; Hurd, C.L. Seaweed nutrient physiology: Application of concepts to aquaculture and bioremediation. Phycologia 2019, 58, 552-562. [CrossRef]

48. Afonso, C.; Correia, A.P.; Freitas, M.V.; Baptista, T.; Neves, M.; Mouga, T. Seasonal Changes in the Nutritional Composition of Agarophyton vermiculophyllum (Rhodophyta, Gracilariales) from the Center of Portugal. Foods 2021, 10, 1145. [CrossRef] [PubMed]

49. Milinovic, J.; Campos, B.; Mata, P.; Diniz, M.; Noronha, J.P. Umami free amino acids in edible green, red, and brown seaweeds from the Portuguese seashore. J. Appl. Phycol. 2020, 32, 3331-3339. [CrossRef]

50. Hamid, S.S.; Wakayama, M.; Soga, T.; Tomita, M. Drying and extraction effects on three edible brown seaweeds for metabolomics. J. Appl. Phycol. 2018, 30, 3335-3350. [CrossRef]

51. Madden, M.; Mitra, M.; Ruby, D.; Schwarz, J. Seasonality of selected nutritional constituents of edible Delmarva seaweeds. J. Phycol. 2012, 48, 1289-1298. [CrossRef]

52. Rocha, C.P.; Pacheco, D.; Cotas, J.; Marques, J.C.; Pereira, L.; Gonçalves, A.M.M. Seaweeds as Valuable Sources of Essential Fatty Acids for Human Nutrition. Int. J. Environ. Res. Public Health 2021, 18, 4968. [CrossRef]

53. Francavilla, M.; Franchi, M.; Monteleone, M.; Caroppo, C. The red seaweed Gracilaria gracilis as a multi products source. Mar. Drugs 2013, 11, 3754-3776. [CrossRef]

54. Institute of Medicine. Dietary Reference Intakes: The Essential Guide to Nutrient Requirements; Meyers, L.D., Hellwig, J.P., Otten, J.J., Eds.; National Academies Press: Washington, DC, USA, 2006.

55. The European Parliament of the European Union Regulation (EU) 1169/2011 on the provision of food information to consumers. Off. J. Eur. Union 2011, 304, 18-63.

56. Milinovic, J.; Rodrigues, C.; Diniz, M.; Noronha, J.P. Determination of total iodine content in edible seaweeds: Application of inductively coupled plasma-atomic emission spectroscopy. Algal Res. 2021, 53, 102149. [CrossRef] 
57. Cundy, T.; Grey, A.; Reid, I.R. Calcium, phosphate and magnesium. In Clinical Biochemistry: Metabolic and Clinical Aspects; Marshall, W.J., Day, A.P., Lapsley, M., Ayling, R.M., Eds.; Elsevier: Amsterdam, The Netherlands, 2014; pp. 93-123.

58. Bhatia, V.; Kulkarni, A.; Nair, V.V. Disorders of Mineral and Bone Metabolism. In Practical Pediatric Endocrinology in a Limited Resource Setting; Zacharin, M., Ed.; Elsevier: Amsterdam, The Netherlands, 2013; pp. 159-186.

59. Penney, M.D. Sodium, water and potassium. In Clinical Biochemistry: Metabolic and Clinical Aspects; Marshall, W.J., Day, P.D., Lapsley, M., Ayling, R.M., Eds.; Elsevier: Amsterdam, The Netherlands, 2014; pp. 27-64.

60. Rao, M.K.; Anderson, S. The Kidney in Aging. In Primer on Kidney Diseases; Greenberg, A., Coffman, T.M., Cheung, A.K., Jennette, J.C., Falk, R.J., Eds.; Elsevier: Amsterdam, The Netherlands, 2009; pp. 413-419.

61. Rude, R.K. Magnesium. In Encyclopedia of Dietary Supplements; Coates, P.M., Betz, J.M., Blackman, M.R., Cragg, G.M., Levine, M., Moss, J., White, J.D., Eds.; Informa Healthcare; Rude RK: New York, NY, USA, 2010; pp. 527-537.

62. Rude, R.K. Magnesium. In Modern Nutrition in Health and Disease; Ross, A.C., Caballero, B., Cousins, R.J., Tucker, K.L., Ziegler, T.R., Eds.; Lippincott Williams \& Wilkins: Baltimore, MD, USA, 2012; pp. 159-175.

63. Whitbread, D. Top 10 Vegetables Highest in Magnesium. Available online: https://www.myfooddata.com/articles/highmagnesium-vegetables.php (accessed on 1 August 2021).

64. Stone, M.; Martyn, L.; Weaver, C. Potassium Intake, Bioavailability, Hypertension, and Glucose Control. Nutrients 2016, 8, 444. [CrossRef]

65. US Department of Health and Human Services. Potassium Fact Sheet for Health Professionals. Available online: https: // ods.od.nih.gov/factsheets/Potassium-HealthProfessional/ (accessed on 18 August 2021).

66. Whitbread, D. 20 Vegetables High in Potassium-A Ranking from Highest to Lowest. Available online: https://www.myfooddata. com/articles/high-potassium-vegetables.php (accessed on 18 August 2021).

67. Nutrition Information for Raw Vegetables /FDA. Available online: https://www.fda.gov/food/food-labeling-nutrition/ nutrition-information-raw-vegetables (accessed on 23 July 2021).

68. Yates, A.A.; Schlicker, S.A.; Suitor, C.W. Dietary Reference Intakes. J. Am. Diet. Assoc. 1998, 98, 699-706. [CrossRef]

69. Allen, L.; de Benoist, B.; Dary, O.; Hurrel, R. Guidelines on Food Fortification with Micronutrients; WHO: Geneva, Switzerland, 2006.

70. Whitbread, D. Top 10 Foods Highest in Manganese. Available online: https://www.myfooddata.com/articles/foods-high-inmanganese.php (accessed on 2 July 2021).

71. National Institute of Health Manganese-Health Professional Fact Sheet. Available online: https://ods.od.nih.gov/factsheets/ Manganese-HealthProfessional/ (accessed on 2 July 2021).

72. Marriott, B.P.; Birt, D.F.; Stallings, V.A.; Yates, A. Present Knowledge in Nutrition: Basic Nutrition and Metabolism; Academic Press: Cambridge, MA, USA, 2020; Volume 1.

73. Li, L.; Yang, X. The Essential Element Manganese, Oxidative Stress, and Metabolic Diseases: Links and Interactions. Oxidative Med. Cell. Longev. 2018, 2018, 7580707. [CrossRef] [PubMed]

74. Aschner, J.L.; Aschner, M. Nutritional aspects of manganese homeostasis. Mol. Asp. Med. 2005, 26, 353-362. [CrossRef]

75. Chen, P. Manganese metabolism in humans. Front. Biosci. 2018, 23, 4665. [CrossRef] [PubMed]

76. Whitbread, D. Top 10 Foods Highest in Zinc. Available online: https://www.myfooddata.com/articles/high-zinc-foods.php (accessed on 2 July 2021).

77. O'Connor, J.M.; Hannigan, B.M.; Strain, J.J.; Bonham, M. The immune system as a physiological indicator of marginal copper status? Br. J. Nutr. 2002, 87, 393-403. [CrossRef]

78. Uriu-Adams, J.Y.; Keen, C.L. Copper, oxidative stress, and human health. Mol. Asp. Med. 2005, 26, 268-298. [CrossRef]

79. Krishnaiah, D.; Sarbatly, R.; Prasad, D.M.R.; Bono, A. Mineral Content of Some Seaweeds from Sabah's South China Sea. Asian J. Sci. Res. 2008, 1, 166-170. [CrossRef]

80. Clark, M.J.; Slavin, J.L. The Effect of Fiber on Satiety and Food Intake: A Systematic Review. J. Am. Coll. Nutr. 2013, 32, $200-211$. [CrossRef] [PubMed]

81. Salehi, B.; Sharifi-Rad, J.; Seca, A.M.; Pinto, D.C.; Michalak, I.; Trincone, A.; Mishra, A.P.; Nigam, M.; Zam, W.; Martins, N. Current Trends on Seaweeds: Looking at Chemical Composition, Phytopharmacology, and Cosmetic Applications. Molecules 2019, $24,4182$. [CrossRef] [PubMed]

82. Lozano Muñoz, I.; Díaz, N.F. Minerals in edible seaweed: Health benefits and food safety issues. Crit. Rev. Food Sci. Nutr. 2020, 1-16. [CrossRef]

83. Pereira, L. Estudos em Macroalgas Carragenófitas (Gigartinales, Rhodophyceae) da Costa Portuguesa-Aspectos Ecológicos, Bioquímicos e Citológicos. Ph.D. Thesis, University of Coimbra, Coimbra, Portugal, 2004.

84. Chopin, T.; Kerin, B.F.; Mazerolle, R. Phycocolloid chemistry as a taxonomic indicator of phylogeny in the Gigartinales, Rhodophyceae: A review and current developments using Fourier transform infrared diffuse reflectance spectroscopy. Phycol. Res. 1999, 47, 167-188. [CrossRef]

85. Zinoun, M.; Cosson, J.; Deslandes, E. Influence of Culture Conditions on Growth and Physicochemical Properties of Carrageenans in Gigartina teedii (Rhodophyceae-Gigartinales). Bot. Mar. 1993, 36, 131-136. [CrossRef]

86. Scientific Opinion on Dietary Reference Values for carbohydrates and dietary fibre. EFSA J. 2010, 8, 1462. [CrossRef]

87. Teas, J. Dietary Seaweed and Breast Cancer: A Randomized Trial. Available online: https:/ clinicaltrials.gov/ct2/show/NCT016 63792 (accessed on 3 October 2021). 
88. Tuohy, K.M.; Probert, H.M.; Smejkal, C.W.; Gibson, G.R. Using probiotics and prebiotics to improve gut health. Drug Discov. Today 2003, 8, 692-700. [CrossRef]

89. Rowland, I. Optimal nutrition: Fibre and phytochemicals. Proc. Nutr. Soc. 1999, 58, 415-419. [CrossRef] [PubMed]

90. EFSA Panel on Dietetic Products, Nutrition and Allergies (NDA). Scientific Opinion on the substantiation of health claims related to dietary fibre (ID 744, 745, 746, 748, 749, 753, 803, 810, 855, 1415, 1416, 4308, 4330) pursuant to Article 13(1) of Regulation (EC) No 1924/2006. EFSA J. 2010, 8, 1735. [CrossRef]

91. Clark, M.J.; Slavin, J.L. Scientific Opinion on the substantiation of health claims related to the replacement of mixtures of saturated fatty acids (SFAs) as present in foods or diets with mixtures of monounsaturated fatty acids (MUFAs) and/or mixtures of polyunsaturated fatty aci. EFSA J. 2011, 9, 2069. [CrossRef]

92. Gibson, G.R.; Hutkins, R.; Sanders, M.E.; Prescott, S.L.; Reimer, R.A.; Salminen, S.J.; Scott, K.; Stanton, C.; Swanson, K.S.; Cani, P.D.; et al. Expert consensus document: The International Scientific Association for Probiotics and Prebiotics (ISAPP) consensus statement on the definition and scope of prebiotics. Nat. Rev. Gastroenterol. Hepatol. 2017, 14, 491-502. [CrossRef] [PubMed]

93. Huebbe, P.; Nikolai, S.; Schloesser, A.; Herebian, D.; Campbell, G.; Glüer, C.-C.; Zeyner, A.; Demetrowitsch, T.; Schwarz, K.; Metges, C.C.; et al. An extract from the Atlantic brown algae Saccorhiza polyschides counteracts diet-induced obesity in mice via a gut related multi-factorial mechanisms. Oncotarget 2017, 8, 73501-73515. [CrossRef] [PubMed]

94. Liu, J.; Kandasamy, S.; Zhang, J.; Kirby, C.W.; Karakach, T.; Hafting, J.; Critchley, A.T.; Evans, F.; Prithiviraj, B. Prebiotic effects of diet supplemented with the cultivated red seaweed Chondrus crispus or with fructo-oligo-saccharide on host immunity, colonic microbiota and gut microbial metabolites. BMC Complement. Altern. Med. 2015, 15, 279. [CrossRef] [PubMed]

95. Cherry, P.; Yadav, S.; Strain, C.R.; Allsopp, P.J.; McSorley, E.M.; Ross, R.P.; Stanton, C. Prebiotics from Seaweeds: An Ocean of Opportunity? Mar. Drugs 2019, 17, 327. [CrossRef]

96. Beaumont, M.; Tran, R.; Vera, G.; Niedrist, D.; Rousset, A.; Pierre, R.; Shastri, V.P.; Forget, A. Hydrogel-Forming Algae Polysaccharides: From Seaweed to Biomedical Applications. Biomacromolecules 2021, 22, 1027-1052. [CrossRef]

97. Morais, T.; Cotas, J.; Pacheco, D.; Pereira, L. Seaweeds Compounds: An Ecosustainable Source of Cosmetic Ingredients? Cosmetics 2021, 8, 8. [CrossRef]

98. Pacheco-Quito, E.-M.; Ruiz-Caro, R.; Veiga, M.-D. Carrageenan: Drug Delivery Systems and Other Biomedical Applications. Mar. Drugs 2020, 18, 583. [CrossRef]

99. Brown, E.M.; Allsopp, P.J.; Magee, P.J.; Gill, C.I.; Nitecki, S.; Strain, C.R.; McSorley, E.M. Seaweed and human health. Nutr. Rev. 2014, 72, 205-216. [CrossRef]

100. Liu, L.; Heinrich, M.; Myers, S.; Dworjanyn, S.A. Towards a better understanding of medicinal uses of the brown seaweed Sargassum in Traditional Chinese Medicine: A phytochemical and pharmacological review. J. Ethnopharmacol. 2012, 142, 591-619. [CrossRef]

101. Kumar, M.S.; Sharma, S.A. Toxicological effects of marine seaweeds: A cautious insight for human consumption. Crit. Rev. Food Sci. Nutr. 2021, 61, 500-521. [CrossRef]

102. Pal, A.; Kamthania, M.C.; Kumar, A. Bioactive Compounds and Properties of Seaweeds-A Review. OALib 2014, 1, 1-17. [CrossRef]

103. Ana, P.; Nathalie, B.; Gilles, B.; Daniel, R.; Tomás, M.-S.; Yolanda, F.-P. Anti-Herpes simplex virus (HSV-1) activity and antioxidant capacity of carrageenan-rich enzymatic extracts from Solieria filiformis (Gigartinales, Rhodophyta). Int. J. Biol. Macromol. 2021, 168, 322-330. [CrossRef] [PubMed]

104. Grassauer, A.; Weinmuellner, R.; Meier, C.; Pretsch, A.; Prieschl-Grassauer, E.; Unger, H. Iota-Carrageenan is a potent inhibitor of rhinovirus infection. Virol. J. 2008, 5, 107. [CrossRef] [PubMed]

105. Moreira Leite, B.S. Novas Alternativas para o Uso de Macroalgas da Costa Portuguesa em Alimentação. Master's Thesis, University of Lisbon, Lisbon, Portugal, 2017.

106. Vaskoska, R.S. Raising a Need for a Risk Assessment of Bromoform Transferred from Feed to Food. Available online: https: / / foodlegal.com.au/inhouse/document/2440 (accessed on 3 July 2021).

107. Kinley, R.D.; Martinez-Fernandez, G.; Matthews, M.K.; de Nys, R.; Magnusson, M.; Tomkins, N.W. Mitigating the carbon footprint and improving productivity of ruminant livestock agriculture using a red seaweed. J. Clean. Prod. 2020, 259, 120836. [CrossRef]

108. Vucko, M.J.; Magnusson, M.; Kinley, R.D.; Villart, C.; de Nys, R. The effects of processing on the in vitro antimethanogenic capacity and concentration of secondary metabolites of Asparagopsis taxiformis. J. Appl. Phycol. 2017, 29, 1577-1586. [CrossRef]

109. Vijn, S.; Compart, D.P.; Dutta, N.; Foukis, A.; Hess, M.; Hristov, A.N.; Kalscheur, K.F.; Kebreab, E.; Nuzhdin, S.V.; Price, N.N.; et al. Key Considerations for the Use of Seaweed to Reduce Enteric Methane Emissions from Cattle. Front. Vet. Sci. 2020, 7, 597430. [CrossRef] [PubMed]

110. Chan, J.C.-C.; Cheung, P.C.-K.; Ang, P.O. Comparative Studies on the Effect of Three Drying Methods on the Nutritional Composition of Seaweed Sargassum hemiphyllum (Turn.) C. Ag. J. Agric. Food Chem. 1997, 45, 3056-3059. [CrossRef]

111. Nitschke, U.; Stengel, D.B. Quantification of iodine loss in edible Irish seaweeds during processing. J. Appl. Phycol. 2016, $28,3527-3533$. [CrossRef]

112. Lucas, M.D.; Sequeira, E.M. Pedologia Determinação do Cu, Zn, Mn, Fe, Ca, Mg, K, e Na Totais das Plantas por Espectrofotometria de Absorção Atómica e Fotometria de Chama. Pedologia 1976, 11, 163-169. 
113. Ribas, M.C.; Veiga, M.E.; Curto, A.; Oliveira, E.; Barbeitos, M.M.; Ferreira, M.; Pacheco, C.; Peralta, M.F.; Duarte, M.L. Métodos de Análise de Material Vegetal e Terras; MAPA—Laboratório Químico Agrícola Rebelo da Silva, Secção de Nutrição das Culturas: Lisboa, Portugal, 1988.

114. Cunniff, P. Official Methods of Analysis of AOAC International; AOAC International: Gaithersburg, MD, USA, 1997.

115. Angell, A.R.; Mata, L.; de Nys, R.; Paul, N.A. The protein content of seaweeds: A universal nitrogen-to-protein conversion factor of five. J. Appl. Phycol. 2016, 28, 511-524. [CrossRef]

116. Pereira, L.; van de Velde, F. Portuguese carrageenophytes: Carrageenan composition and geographic distribution of eight species (Gigartinales, Rhodophyta). Carbohydr. Polym. 2011, 84, 614-623. [CrossRef] 